\title{
CHEMICAL, CLINICAL, AND IMMUNOLOGICAL STUDIES ON THE PRODUCTS OF HUMAN PLASMA FRACTIONATION.
}

\author{
XI. THE USE OF CONCENTRATED NORMAL HUMAN SERUM \\ GAMMA GLOBULIN (HUMAN IMMUNE SERUM GLOBULIN) \\ IN THE PROPHYLAXIS AND TREATMENT OF MEASLES 1,2
}

\author{
BY J. STOKES, JR., E. P. MARIS, AND S. S. GELLIS \\ (From the Department of Pediatrics, School of Medicine, University of Pennsylvania \\ and Children's Hospital of Philadelphia, and the Department of \\ Pediatrics, Johns Hopkins Medical School, Baltimore)
}

(Received for publication February 17, 1944)

\section{INTRODUCTION}

Human immune bodies, obtained from the blood of individuals who have had measles, when injected parenterally in exposed susceptibles in sufficient quantities and at a suitable interval from the time of exposure, have long been recognized as useful in attenuating or in passively protecting against measles. In the process of fractionation of pooled human plasma, developed for the production of normal human serum albumin by Cohn, Oncley, Strong, Hughes and Armstrong (1), fractions became available in which a variety of antibodies, reacting with certain viruses and bacteria, were found by Enders to be concentrated many times (2). It became obvious that such concentrated preparations of antibodies should be useful against those diseases for which the attenuating, protective, or curative value of human immune plasma or sera had been demonstrated. The present report presents: A. A study of the use of such globulin fractions of human plasma for attenuation or passive protection against measles in 891 individuals who, as far as could be determined, were exposed susceptibles. B. A study of the use of globulin fractions containing the largest proportion of im-

\footnotetext{
1 These investigations were aided in part through the Commission on Measles and Mumps, Board for the Investigation and Control of Influenza and other Epidemic Diseases in the Army, Preventive Medicine Division, Office of the Surgeon General, United States Army.

2 The products of plasma fractionation employed in this work were developed from blood, collected by the American Red Cross, by the Department of Physical Chemistry, Harvard Medical School, Boston, Massachusetts, under a contract, recommended by the Committee on Medical Research, between the Office of Scientific Research and Development and Harvard University.
}

mune bodies (chiefly gamma globulin) in the treatment of 61 individuals during the early stages of measles.

\section{A. PASSIVE IMMUNIzATION}

\section{Materials used for prophylaxis}

Two globulin fractions were used in these studies, Fraction II + III in the early work and Fraction II for most of the period of investigation. In Fraction II + III, the first crude concentrate containing all the gamma globulins and considerable beta globulin (1), Enders found the theoretically expected 8 to 10 -fold concentration of many antibodies present in normal pooled plasma (2). In Fraction II, the gamma globulins and antibodies were further purified (1), so that the titer of those antibodies which appeared in this fraction (2) was from 15 to 35 times as high as in the original plasma pool.

In view of the concentration of immune bodies reacting with viruses in Fraction II, it appeared that the value of this fraction in measles should receive the more intensive study. Thus, a few preliminary tests were made of the value in measles of Fraction II + III, while the bulk of the data collected concerns the studies of Fraction II.

\section{Clinical material}

A measles epidemic, occurring through the winter of 1942 to 1943 and the spring of 1943 in the Philadelphia area, afforded the opportunity for a study of the value of the globulin fractions. Also, in the spring of 1943 in the Baltimore area, a measles epidemic appeared which gained little headway during the summer. However, in both areas, the disease was of considerably greater than average severity, -an opinion based first upon the relatively high incidence of cases of measles encephalitis; second upon the ease and severity with which monkeys contracted the disease when injected with blood from acute cases (3); and third, upon the high fever, extent of the rash, and other clinical signs and symptoms present. Most of the children studied resided in the Philadelphia area, while a smaller group was included from Baltimore. In the latter area, the results were obtained by one of the authors (S. S. G.); while in 
Philadelphia, with the exception of those injected by the authors, the children studied were private patients, either of members of the Medical Staff of the Children's'Hospital or, with a few exceptions, of physicians associated with this Hospital.?

Inasmuch as attenuation rather than complete protection was usually desired, the continuous central tabulation of the results obtained from the physicians in the Philadelphia area permitted in general a uniform reduction in the amount of globulin they injected during the course of the epidemic. A similar reduction in dosage resulted in the Baltimore area. While, in this manner, the children injected early in the study were most frequently protected from measles, with the reduction in dosage, attenuation was frequently obtained and the amounts which offered the best chance of obtaining either result were thus estimated more accurately.

The injections were intramuscular. The physicians were encouraged to inject susceptibles who were intimately exposed in their homes (not at school or out-of-doors) and within 7 days of the time of exposure. Control groups were obtained in 3 schools, a large number of homes, and 1 institution (Table I). In the 3 schools, 54 children, or 68

TABLE I

Incidence of measles in control children in three private schools-Philadelphia 1943

Total enrollment

170

Untraceable

Previous measles

Received passive immunization

Unexposed

Total non-susceptibles

Total susceptibles

Contracted measles. Winter 1943

Failed to contract measles on exposure

Contracted measles

Failed to contract measles

68 per cent

32 per cent

per cent of 79 exposed children who gave no history of measles, developed the disease. In the homes, over 90 per cent of the exposed susceptibles with negative histories contracted measles, while in the 1 institution, 43 of 44 children studied developed measles. Because of the severity of the epidemic, it was deemed inadvisable to request families to permit certain of their children to remain unprotected as controls.

The largest groups of children in the Philadelphia area were furnished by Drs. Charles $\mathbf{H}$. Classen, S. Emlen Stokes, Howard S. Curtis, John P. Scott, and Jeannette Munro. In addition, groups of appreciable size were furnished by Drs. Harriet Felton, Sherman Little, Julian M. Lyon, James Reilly, Joseph Ritter, and Elizabeth Rose. Smaller groups were studied by Drs. Charles C. Chapple, Arthur M. Dannenberg, Charles Munro, Arthur Peacock, Stuart Polk, Milton Rapoport, and Mitchell Rubin.

\section{Results}

The total number of individuals injected with both globulin fractions, either for attenuation or for complete protection, amounted to 891. A few of this group were adults who professed never to have suffered from measles and who usually requested a sufficient quantity of globulin to insure complete protection. A considerably larger number of children were injected well after the seventh day from exposure with an amount of globulin which could not have been expected either to protect them or to attenuate the disease. Because of the insistence of worried parents, it is frequently impossible for the physician to avoid the use of globulin in children for whom it is not indicated because of early exposure. The number of children injected with Fraction II + III was not sufficient to permit quantitative determinations of the amounts required for protection and attenuation, respectively. Accurate estimates concerning the value of this fraction were particularly difficult, in view of the fact that it was the first fraction tested and usually larger amounts than necessary were injected.

The terms used to describe measles in the injected groups were (1) no measles, (2) very mild measles, (3) mild measles, and (4) unmodified measles. The first and fourth categories were clear-cut and, on the whole, easily estimated. Very mild measles was estimated primarily by means of a temperature which did not rise above $101^{\circ} \mathrm{F}$., or which had a single spike of temperature on one day, rising above $101^{\circ} \mathrm{F}$. but not above $102^{\circ} \mathrm{F}$. In such cases, also, the rash was usually sparse, the respiratory signs and symptoms were slight, and the patient was not acutely ill. For the category of mild measles, the temperature remained below $103^{\circ} \mathrm{F}$. and other signs and symptoms of measles were obviously mild. The number of cases in this category fortunately were few, since most children could be considered as falling into the second category of very mild measles. An over-all summary of the results which includes all cases injected, without reference to the age, time or type of exposure, or amount of globulin used, is included in Table II. In this summary, the lack of knowledge at first of the excellent protective value of the globulin 
TABLE II

Final results in individuals to whom gamma globulin was given as a prophylactic measure against measles-Winter 1943

\begin{tabular}{l|r|r|r|r|r|r}
\hline \hline No measles & $\begin{array}{c}\text { Num- } \\
\text { ber }\end{array}$ & $\begin{array}{c}\text { Per } \\
\text { cent }\end{array}$ & $\begin{array}{c}\text { Num- } \\
\text { ber }\end{array}$ & $\begin{array}{c}\text { Per } \\
\text { cent }\end{array}$ & $\begin{array}{c}\text { Num- } \\
\text { ber }\end{array}$ & $\begin{array}{c}\text { Per } \\
\text { cent }\end{array}$ \\
\hline Very mild measles & 191 & 69.40 & 618 & 71.36 & & \\
\hline Mild measles & 57 & 6.36 & 248 & 28.64 & 866 & 97.2 \\
\hline Unmodified measles & 25 & 2.80 & & & 25 & 2.8 \\
\hline Total & 891 & 100.0 & 866 & 100.0 & 891 & 100.0 \\
\hline
\end{tabular}

is evident in the large number of individuals who suffered no measles, while the insistence of families upon its use, despite too early an exposure, is evident in the group of unmodified cases. Also, the inclusion of casually exposed individuals in this table, although not a large group, conveys a false impression of the number who were completely protected by the globulin.

For the foregoing reasons, it was necessary to select from the entire tabulation those individuals for whom rigid criteria of age, type of exposure, time of exposure, and amount of globulin could be fulfilled. In order to fulfill such criteria, two age groups of children were selected.
The first was a pre-school group from 1 to 5 years, inclusive, which was considered as 100 per cent susceptible. The age range of the second group was 6 to 12 years, inclusive. These children also were suceptibles as far as could be determined, although the history of absence of measles at this age-range is somewhat less reliable. In Figure 1 are indicated the age ranges of the children within the two groups selected. Home exposures only were included and only children in whom the globulin had been injected within 7 days of exposure. The percentages of no measles in these two age groups of children are plotted against the amount of globulin injected to form the two curves shown in Figure 2. These two curves are not extended to the right beyond the dosage of 2 and $2.5 \mathrm{cc}$., nor to the left as far as the dosage of $0.25 \mathrm{cc}$., because there were not sufficient children in these ranges and beyond to furnish data which were statistically valid. However, the small amount of data available suggested that the curves would ascend rapidly towards the 100 per cent point, inasmuch as a group of 39 out of 40 individuals of all ages, injected with 4 or $5 \mathrm{cc}$. and fulfilling the criteria of time and type of exposure, did not contract measles. The complete data from which Figure 2 is derived are shown in Table III.

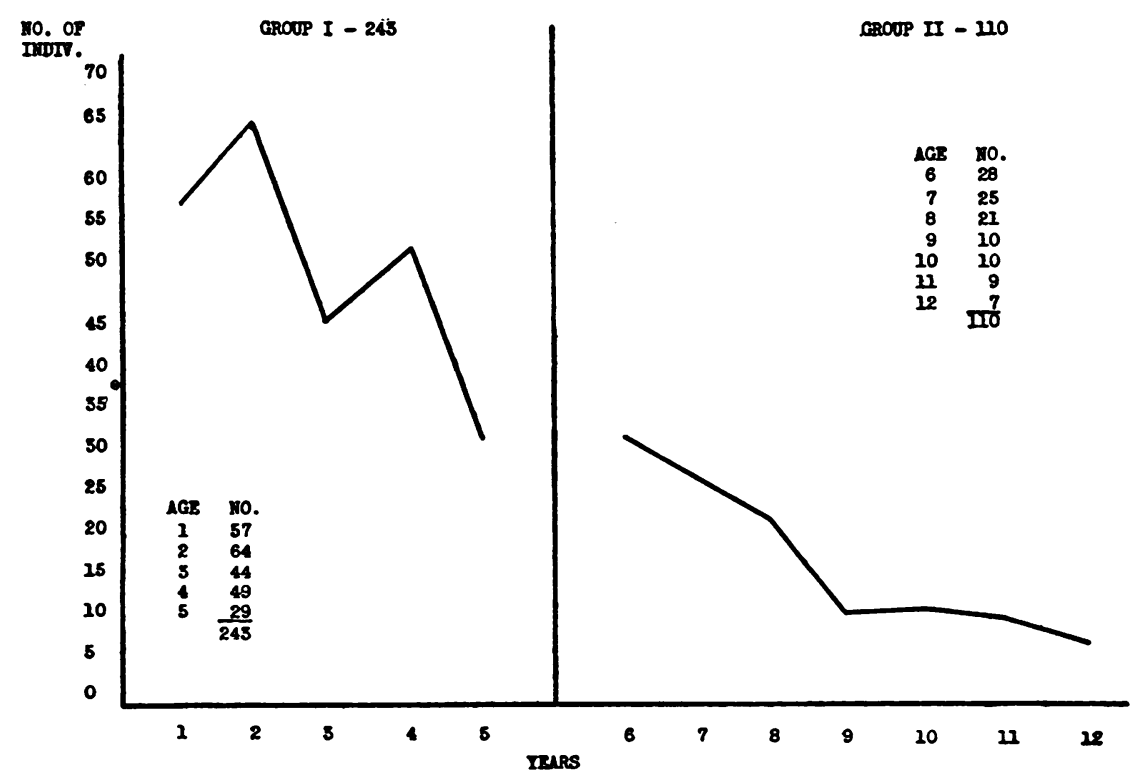

Fig. 1. Prophylactic Administration of Gamma Globulin Fraction II Against Measleg-Age Incidence of Selected Groups 


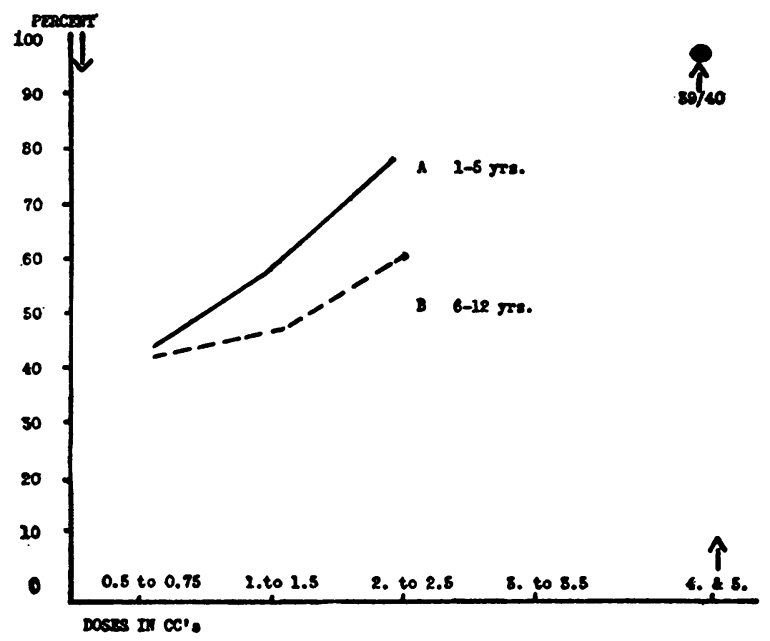

Fig. 2. Percentage of No Measles Versus Mild Measles in Relation to Graded Doses of Gama Globulin Given to Selected Groups

\section{Discussion}

The striking value of Fraction II of the immune globulin for protection against measles is evident from the foregoing data. That it is the most potent product thus far developed for this purpose is also evident, inasmuch as doses of 0.5 cc., when injected within a suitable period in susceptibles exposed at home and in both the age ranges studied, afforded approximately an equal chance of no measles or of attenuation. When the dose was increased to 2 to $2.5 \mathrm{cc}$. in the same age ranges and under the same conditions, the chances of no measles were approximately from 66 per cent to 80 per cent. Also at this dosage level, with almost no exceptions (2 out of 70), the children who were not completely protected had measles which was considerably attenuated.

The curves of Figure 2 demonstrate clearly a finding which cannot be too strongly emphasized in studies of measles prophylaxis, namely, that within a rather wide range of dosage, protection or attenuation still remains a matter of chance. In such studies, this chance can be estimated with considerable accuracy for a group of children, but the physician cannot as yet give the answer to the parents of the exposed susceptible as to whether or not their child will have attenuation or protection within a specified range of dosage. The reason for such difficulty in the selection of the amount of globulin would appear

TABLE III

Analysis of protection against measles afforded by gamma globulin in selected groups-1943

\begin{tabular}{|c|c|c|c|c|c|c|c|c|c|c|c|c|}
\hline & \multicolumn{2}{|c|}{0.5 and $0.75 \mathrm{cc}$. } & \multicolumn{2}{|c|}{1.0 and $1.5 \propto c}$. & \multicolumn{2}{|c|}{2.0 and $2.5 \propto$} & \multicolumn{2}{|c|}{3.0 and $3.5 \mathrm{cc}$. } & \multicolumn{2}{|c|}{4.0 and $5.0 \propto c$} & \multirow[b]{2}{*}{ Totals } & \multirow{2}{*}{ Per cent } \\
\hline & $\underset{\text { ber }}{\text { Num- }}$ & $\begin{array}{l}\text { Per } \\
\text { cent }\end{array}$ & $\underset{\text { ber }}{\text { Num- }}$ & $\begin{array}{c}\text { Per } \\
\text { cent }\end{array}$ & $\underset{\text { ber }}{\text { Num- }}$ & $\begin{array}{c}\text { Per } \\
\text { cent }\end{array}$ & $\underset{\text { ber }}{\text { Num- }}$ & $\begin{array}{l}\text { Per } \\
\text { cent }\end{array}$ & $\underset{\text { ber }}{\text { Num- }}$ & $\begin{array}{c}\text { Per } \\
\text { cent }\end{array}$ & & \\
\hline $\begin{array}{l}\text { Ages } \\
1 \text { to } 5 \text { years } \\
\text { No measles } \\
\text { Very mild and mild measles }\end{array}$ & $\begin{array}{l}39 \\
48\end{array}$ & $\begin{array}{l}45 \\
55\end{array}$ & $\begin{array}{l}51 \\
35\end{array}$ & $\begin{array}{l}57 \\
43\end{array}$ & $\begin{array}{r}39 \\
9\end{array}$ & $\begin{array}{l}80 \\
20\end{array}$ & $\begin{array}{l}8 \\
4\end{array}$ & $\begin{array}{l}67 \\
33\end{array}$ & $\begin{array}{l}4 \\
0\end{array}$ & $\begin{array}{r}100 \\
0\end{array}$ & $\begin{array}{r}141 \\
96\end{array}$ & $\begin{array}{l}59.5 \\
40.5\end{array}$ \\
\hline Total & 87 & 100 & 86 & 100 & 48 & 100 & 12 & 100 & 4 & 100 & 237 & 100.0 \\
\hline $\begin{array}{l}\text { Ages } \\
\quad 6 \text { to } 12 \text { years } \\
\text { No measles } \\
\text { Very mild and mild measles }\end{array}$ & $\begin{array}{l}15 \\
19\end{array}$ & $\begin{array}{l}44 \\
56\end{array}$ & $\begin{array}{l}16 \\
18\end{array}$ & $\begin{array}{l}47 \\
53\end{array}$ & $\begin{array}{r}12 \\
8\end{array}$ & $\begin{array}{l}60 \\
40\end{array}$ & $\begin{array}{l}9 \\
6\end{array}$ & $\begin{array}{l}60 \\
40\end{array}$ & $\begin{array}{l}3 \\
1\end{array}$ & $\begin{array}{l}75 \\
25\end{array}$ & $\begin{array}{l}55 \\
52\end{array}$ & $\begin{array}{l}51.4 \\
48.6\end{array}$ \\
\hline Total & 34 & 100 & 34 & 100 & 20 & 100 & 15 & 100 & 4 & 100 & 107 & 100.0 \\
\hline $\begin{array}{l}\text { Over } 12 \text { years } \\
\text { No measles } \\
\text { Very mild and mild measles }\end{array}$ & $\begin{array}{l}8 \\
1\end{array}$ & $\begin{array}{l}89 \\
11\end{array}$ & $\begin{array}{l}4 \\
0\end{array}$ & $\begin{array}{r}100 \\
0\end{array}$ & $\begin{array}{l}6 \\
2\end{array}$ & $\begin{array}{l}75 \\
25\end{array}$ & $\begin{array}{l}5 \\
2\end{array}$ & $\begin{array}{l}71 \\
29\end{array}$ & $\begin{array}{r}32 \\
0\end{array}$ & $\begin{array}{r}100 \\
0\end{array}$ & $\begin{array}{r}55 \\
5\end{array}$ & $\begin{array}{r}91.7 \\
8.3\end{array}$ \\
\hline Total & 9 & 100 & 4 & 100 & 8 & 100 & 7 & 100 & 32 & 100 & 60 & 100.0 \\
\hline
\end{tabular}

Measles total in age groups under 13 years

No measles...................... 196- 57 per cent

Very mild and mild measles............. 148- 43 per cent 
to lie in the difference in susceptibility of individual children. This difference appears to be clearly indicated when a large family of susceptibles, similarly exposed, suffer measles of varying severity. In such a consideration, it is assumed that the virus strain in a single epidemic remains the same.

Despite the inability to determine for each child the size of dose which will protect or attenuate within the dosage range shown in Figure 2 , nevertheless when doses are selected either to the left or right of the curves indicated, i.e., below $0.25 \mathrm{cc}$. or above 4 to $5 \mathrm{cc}$., the parents can be given considerable assurance as to whether or not measles will occur in their exposed susceptibles. The same criteria obviously also apply to adult susceptibles. In general, therefore, the amounts necessary for protection and for attenuation may be outlined as follows:

\begin{tabular}{|c|c|c|}
\hline & For attenuation & For protection \\
\hline $\begin{array}{l}\text { Children } 5 \text { years and } \\
\text { under }\end{array}$ & 0.25 to $0.5 \mathrm{cc}$. & $2.0 \mathrm{cc}$. to $2.5 \mathrm{cc}$. \\
\hline $\begin{array}{l}\text { Children } 6 \text { to } 12 \text { years, } \\
\text { inclusive }\end{array}$ & $1 \mathrm{cc}$. to $1.5 \mathrm{cc}$. & $4.0 \mathrm{cc}$. to $5.0 \mathrm{cc}$. \\
\hline
\end{tabular}

Again it must be emphasized that these are approximate figures, due to the difference in susceptibility of individuals.

In any attempt to outline the dosage per pound of body weight, a greater number of cases must be collected. Approximate estimations of proper dosage per pound of body weight, at all ages up to 12 years, are as follows: For attenuation, $0.02 \mathrm{cc}$. per pound; for protection, $0.08 \mathrm{cc}$. per pound. It is interesting that these results are in close agreement with those of Ordman, Jennings, and Janeway, as recorded in the following paper in this series (4).

The advantages of the gamma globulin fraction of plasma, used in these studies, above other preparations of human immune bodies lie primarily in the small size of the dose required, the absence of materials other than those present in plasma, the absence of discomfort or reaction at the site of injection, and the absence of any generalized reaction. When this fraction is obtained from large pools of blood, such as those of the American Red Cross, there is in general a uniformity of antibody titer. Differences in the various samples of Fraction II in these studies were not noted, although the nature of the studies prevented the determination of moderate changes in antibody titer. The general impression was gained, corroborated by the laboratory studies of Dr. John Enders and his co-workers, that Fraction II + III required a larger dose for the same effect as that obtained by Fraction II.

In a few samples of Fraction II, "burning" at the site of injection was noted. This infrequent reaction appeared to depend, at least in part, upon a low $\mathrm{pH}, 6.1$ to 6.2 , of certain early preparations. The $\mathrm{pH}$ has now been standardized at $\mathrm{pH} 6.8 \pm 0.4$.

A final answer to the question of dosage depends upon the well-recognized variables which should again be emphasized.

(1) Age or weight of individual.

(2) Intimacy of exposure.

(3) Length of time from first exposure.

(4) Susceptibility of the individual, which probably includes the season of the year. In summer, individuals appear to be less susceptible, although no conclusive data are available concerning this question.

(5) The desire for complete protection or for attenuation. The general health of the child, the presence of other infectious diseases in the household or the community, the requirements of the social environment, activities, travel, convenience, etc., are all important considerations.

(6) The potency of the prophylactic agent used, particularly as related to improper handling by the physician or distributor.

When such variables are given full consideration by the physician, the proper dose of globulin Fraction II for the individual case may be obtained from such observations as are recorded in Figure 2 and Table III. In any final decision, the variable chances of complete protection or attenuation should be explained to the parents or the patient over the range of dosage thus indicated.

\section{Summary}

The serum gamma globulin, separated and concentrated by chemical fractionation of normal human blood, has been used in studies on measles prophylaxis. Two fractions, II + III, and Frac- 
TABLE IV

Gamma globulin in treatment of measles-1943-a comparison of treated and untreated children PRE-RASH RASE

\begin{tabular}{|c|c|c|c|c|c|c|c|c|c|}
\hline Initials & Age & Dose & Result* & Contact Controls & Initials & Age & Dose & Result & Contact Controls \\
\hline $\begin{array}{l}\text { A. B. } \\
\text { A. G. } \\
\text { N. S. } \\
\text { G. M. A. } \\
\text { L. D. } \\
\text { J. G. } \\
\text { T. N. D. } \\
\text { A. L. }\end{array}$ & 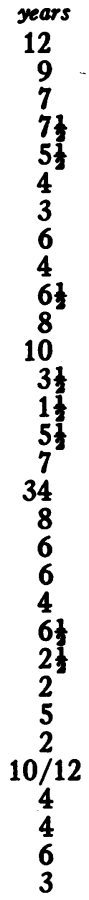 & $\begin{array}{r}c c . \\
15 \\
15 \\
13 \\
15 \\
10 \\
12 \\
5 \\
5 \\
10 \\
15 \\
15 \\
10 \\
12 \\
8 \\
12 \\
5 \\
10 \\
10 \\
5 \\
5 \\
10 \\
5 \\
12 \\
20 \\
20 \\
20 \\
20 \\
20 \\
20 \\
20 \\
20\end{array}$ & $\begin{array}{l}\text { GM } \\
\text { SM } \\
\text { UM } \\
\text { GM } \\
\text { GM** } \\
\text { GM } \\
\text { UM } \\
\text { GM } \\
\text { UM } \\
\text { SM } \\
\text { UM } \\
\text { GM } \\
\text { GM } \\
\text { GM } \\
\text { UM } \\
\text { SM } \\
\text { UM*** } \\
\text { GM** } \\
\text { GM } \\
\text { SM } \\
\text { UM } \\
\text { SM } \\
\text { GM } \\
\text { GM } \\
\text { GM } \\
\text { SM } \\
\text { GM } \\
\text { GM } \\
\text { GM } \\
\text { GM }\end{array}$ & $\begin{array}{l}\text { Not known. } \\
\text { Not known. } \\
\text { Not known. } \\
4 \text { very severe. } \\
\text { Not known. } \\
\text { Not known. } \\
\text { Not known. } \\
\text { Not known. } \\
\text { Moderate. } \\
\text { Not known. } \\
\text { Mild. } \\
\text { Mild. } \\
\text { Sibling, average. } \\
\text { Sibling, average. } \\
\text { Sibling, average. } \\
\text { Severe. } \\
\text { Moderate. } \\
\text { Not known. } \\
\text { Sibling, average. } \\
\text { Not known. } \\
\text { Not known. } \\
\text { Not known. } \\
\text { Not known. } \\
2 \text { average. } \\
1 \text { average. } \\
1 \text { average. } \\
3 \text { average. } \\
1 \text { average. } \\
2 \text { average. } \\
4 \text { average. } \\
3 \text { average. }\end{array}$ & $\begin{array}{l}\text { S. E. } \\
\text { M. L. } \\
\text { L. S. } \\
\text { K. F. } \\
\text { L. W. } \\
\text { G. C. } \\
\text { A. L. } \\
\text { B. McD. } \\
\text { N. A. } \\
\text { R. McC. } \\
\text { P. S. } \\
\text { R. D. } \\
\text { A. H. } \\
\text { C. H. } \\
\text { S. R. } \\
\text { A. P. } \\
\text { G. R. } \\
\text { L. T. } \\
\text { J. K. } \\
\text { Mrs. N. } \\
\text { T. L. } \\
\text { D. V. } \\
\text { B. N. } \\
\text { B. P. } \\
\text { W. J. W. } \\
\text { J. B. } \\
\text { L. K. } \\
\text { P. J. } \\
\text { J. F. } \\
\text { L. T. }\end{array}$ & $\begin{array}{c}\text { years } \\
2 \frac{1}{2} \\
7 \\
3 \\
7 \\
6 \frac{1}{3} \\
5 \frac{1}{3} \\
17 \\
17 \\
7 \\
1 \\
13 \\
10 \\
7 \\
1 \frac{1}{4} \\
8 \\
7 \frac{1}{2} \\
5 \\
5 \frac{1}{3} \\
25 \\
3 \\
6 \\
7 \\
5 \\
6 \\
11 \\
5 \\
7 \\
5 \\
4\end{array}$ & $\begin{array}{r}c c . \\
10 \\
15 \\
7 \\
8 \\
12 \\
10 \\
30 \\
25 \\
10 \\
71 \\
10 \\
10 \\
10 \\
10 \\
15 \\
9 \\
15 \\
10 \\
5 \\
35 \\
20 \\
20 \\
20 \\
20 \\
20 \\
20 \\
20 \\
20 \\
15 \\
10\end{array}$ & $\begin{array}{l}\text { UM } \\
\text { SM } \\
\text { SM } \\
\text { GM } \\
\text { UM } \\
\text { UM } \\
\text { UM } \\
\text { SM } \\
\text { UM } \\
\text { UM } \\
\text { UM } \\
\text { UM } \\
\text { UM } \\
\text { GM } \\
\text { UM } \\
\text { SM } \\
\text { UM } \\
\text { UM } \\
\text { UM } \\
\text { UM } \\
\text { UM } \\
\text { SM } \\
\text { SM } \\
\text { SM } \\
\text { UM } \\
\text { UM } \\
\text { GM } \\
\text { UM } \\
\text { GM } \\
\text { GM }\end{array}$ & $\begin{array}{l}\text { Very severe. } \\
\text { Not known. } \\
\text { Mod. severe. } \\
\text { Not known. } \\
\text { Not known. } \\
\text { Not known. } \\
\text { Not known. } \\
\text { Not known. } \\
\text { Not known. } \\
\text { Mild. } \\
\text { Average case. } \\
\text { Not known. } \\
\text { Not known. } \\
1 \text { average. } \\
\text { Not known. } \\
\text { Not known. } \\
\text { Not known. } \\
\text { Not known. } \\
\text { Not known. } \\
\text { Not known. } \\
2 \text { average. } \\
2 \text { average. } \\
2 \text { average. } \\
3 \text { severe. } \\
2 \text { average. } \\
1 \text { severe. } \\
1 \text { average. } \\
2 \text { average. } \\
2 \text { average. } \\
1 \text { severe. }\end{array}$ \\
\hline
\end{tabular}

tion II, were used. Sufficient data for valid conclusions were obtained with Fraction II. With strict criteria of age, time of exposure, and amount of globulin, curves demonstrating the percentage of no measles of two age groups over a range of dosage were developed. The striking value of Fraction II of human globulin for protection against and attenuation of measles was evident. For size of dosage and ease of injection, gamma globulin Fraction II surpasses other types of human immune bodies.

\section{B. TREATMENT}

\section{Introduction}

The use of large amounts of convalescent measles serum in the treatment of measles during its early stages has been studied by Levinson (5). The generally favorable results obtained by these workers have been confirmed by a few unpublished records from the Philadelphia Serum Exchange of the Children's Hospital of Philadelphia and from other workers. Clearly demonstrable attenuation of the disease in such studies has occurred only when the convalescent serum has been injected in large amounts intravenously at the time of appearance of Koplik spots and before the appearance of any rash.

The demonstration of a high concentration of immune bodies against measles in the gamma globulin Fraction II of pooled human plasma, as indicated previously in this report, suggested the possible value of large amounts of this fraction injected intramuscularly for the treatment of measles in its early stages. Part B of the present report records the results of such studies.

- This fraction of gamma globulin has been released for intramuscular use only. The preparation of an immune serum globulin fraction suitable for intravenous use is being attempted at present. 


\section{Material used for treatment}

Fraction II + III was used for 8 children early in this study, while Fraction II, in view of its high titer of antiinfluenza $A$ antibody and its demonstrated value for protection against or attenuation of measles, as outlined in Part A, was later selected for 53 children. The amount of gamma globulin available was somewhat limited during the major part of the studies on prophylaxis and until a valuable body of data was obtained in the studies of Part A, it did not appear justifiable to use large quantities of Fraction II in studies on treatment.

\section{Clinical Material}

Sixty-one individuals are included in this report. The age range of this group is shown in Table IV. Those selected were as far as possible young children in whom a specified amount of globulin, when considered in relation to the size and weight of the individual, would be relatively more effective. The range of dosage used is also shown in Tables V and VI. The wide variation of dosage is due to lack of accurate knowledge concerning the antibody con- tent of the globulin and the individual choices of physicians who attempted to judge the size of the dose given for treatment by their developing experience with Fraction II in prophylaxis. The difficulties of obtaining a large group of individuals in the home for treatment of measles before the rash has appeared or even during the earliest phases of the rash are far greater than may at first be supposed. The great majority of parents hesitate to call a physician during the earliest stages of any disease. This is particularly true of early measles, with its resemblance to the common cold, for which parents usually delay in calling a physician. In most children, the rash of measles appears before the decision is made.

\section{Results}

The individuals treated with the gamma globulin are best divided into two groups, according to presence or absence of rash at the time of injection. The rash by no means appears in a specified number of days from the beginning of the disease, but the sequence of events is fairly

TABLE V

Analysis of results of treatment with gamma globulin BEFORE RASH-KOPLIK'S SPOTS PRESENT-31

RASH PRESENT-30

\begin{tabular}{|c|c|c|c|c|c|c|c|c|c|c|c|c|c|c|c|c|c|}
\hline \multirow[b]{2}{*}{ Age } & \multicolumn{7}{|c|}{ Dosage } & \multicolumn{10}{|c|}{ Dosage } \\
\hline & 5 & 8 & 10 & 12 & 13 & 15 & 20 & 5 & $\begin{array}{c}7 \\
\text { and } \\
7.5\end{array}$ & 8 & 9 & 10 & 12 & 15 & 20 & 25 & $\begin{array}{l}30 \\
\text { to } \\
35\end{array}$ \\
\hline $\begin{array}{c}\text { years } \\
10 / 12 \\
1 \\
2 \\
3 \\
4 \\
5\end{array}$ & $1 G$ & $1 G$ & $\begin{array}{l}1 G \\
1 S \\
1 G\end{array}$ & $\begin{array}{l}c c . \\
1 S \\
1 G \\
1 G^{*} \\
1 G\end{array}$ & & & $\begin{array}{c}1 S \\
2 G \\
1 G \\
2 G \\
1 G\end{array}$ & & $\begin{array}{l}1 \mathrm{U} \\
1 \mathrm{~S}\end{array}$ & & & $\begin{array}{l}1 \mathrm{G} \\
1 \mathrm{U} \\
1 \mathrm{G} \\
2 \mathrm{U}\end{array}$ & & $1 G$ & $\begin{array}{l}1 \mathrm{U} \\
1 \mathrm{G} \\
1 \mathrm{~S}\end{array}$ & & \\
\hline $\begin{array}{r}6 \\
7 \\
8 \\
9 \\
10 \\
11 \\
12\end{array}$ & $\begin{array}{l}2 \mathrm{G}^{* *} \\
2 \mathrm{U} \\
1 \mathrm{U}\end{array}$ & & $\begin{array}{l}1 \mathrm{U} \\
1 \mathrm{U}\end{array}$ & & $1 S$ & $\begin{array}{l}1 \mathrm{U} \\
1 \mathrm{U} \\
1 \mathrm{~S} \\
1 \mathrm{~S} \\
1 \mathrm{G}\end{array}$ & $1 G$ & $1 \mathrm{U}$ & & $1 G$ & $1 S$ & $\begin{array}{l}2 \mathrm{U} \\
1 \mathrm{U}\end{array}$ & $1 G$ & $\begin{array}{l}1 \mathrm{~S} \\
1 \mathrm{U} \\
1 \mathrm{U}\end{array}$ & $\begin{array}{l}1 \mathrm{~S} \\
1 \mathrm{U} \\
1 \mathrm{~S} \\
1 \mathrm{U} \\
1 \mathrm{U}\end{array}$ & & \\
\hline $\begin{array}{l}\text { Over } 12^{* * * *} \\
\text { (34 years) }\end{array}$ & & & $1 S$ & & & & & & & & & $1 \mathrm{U}$ & & & & $1 S$ & $2 \mathrm{U}$ \\
\hline Totals & $\begin{array}{l}6 \\
3 G \\
3 U\end{array}$ & $\begin{array}{l}1 \\
1 G\end{array}$ & $\begin{array}{l}5 \\
2 G \\
1 S \\
2 U\end{array}$ & $\begin{array}{l}4 \\
3 G \\
1 S\end{array}$ & $\begin{array}{l}1 \\
1 S\end{array}$ & $\begin{array}{l}5 \\
1 G \\
2 S \\
2 U\end{array}$ & $\begin{array}{l}8 \\
7 G \\
1 S\end{array}$ & $\begin{array}{l}1 \\
1 U\end{array}$ & $\begin{array}{l}2 \\
1 S \\
1 \mathrm{U}\end{array}$ & $\begin{array}{l}1 \\
1 G\end{array}$ & $\begin{array}{l}1 \\
1 S\end{array}$ & $\begin{array}{l}8 \\
2 G \\
6 U\end{array}$ & $\begin{array}{l}1 \\
1 G\end{array}$ & $\begin{array}{l}4 \\
1 G \\
1 S \\
2 U\end{array}$ & $\begin{array}{l}8 \\
1 G \\
3 S \\
4 U\end{array}$ & & \\
\hline $\begin{array}{l}\text { G-Greatly } \\
\text { S-Slightly } \\
\text { U-Unmod }\end{array}$ & $\begin{array}{l}\text { difiec } \\
\text { difie }\end{array}$ & & & & & & & $\begin{array}{l}* \mathrm{De} \\
* * \mathrm{O}\end{array}$ & de & no & h. & & ith & 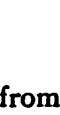 & & als. & \\
\hline
\end{tabular}


TABLE VI

Summary of results of treatment with gamma globulin **

\begin{tabular}{c|c|c|c}
\hline \hline \multicolumn{1}{c|}{ Ages } & & Pre-rash & Rash \\
\cline { 2 - 3 } years & & & \\
& GM & $13^{*}$ & 4 \\
& SL. M & 3 & 2 \\
UN. M & 0 & 5 \\
\hline Totals & & 16 & 11 \\
\hline \multirow{2}{*}{6 to 12} & GM & $4^{*}$ & 2 \\
& SL. M & 3 & 4 \\
& UN. M & 7 & 9 \\
\hline Totals & & 14 & 15 \\
\hline
\end{tabular}

GM-Greatly modified.

SL. M-Slightly modified.

UN. M-Unmodified.

* No rash developed in one.

** Five in group 13 years and over omitted.

uniform, with coryza, conjunctivitis, and Koplik spots preceding the rash by many hours. The lack of such a sequence, at least of the Koplik spots and rash, made early therapy more difficult in a few of those treated. Despite this irregularity, no other landmarks in the field of measles are as stable as these two. This is well demonstrated in Figures 3 and 4 which show data from an epidemic of measles, which occurred during February and March, 1943, in a home for preschool children. The irregularity of appearance of rash following the first signs and symptoms, including Koplik spots, is striking. Because of a special study, all of the children were examined daily or twice daily by the authors, both preceding and throughout the epidemic. The patients were divided, as indicated in Figure 5, according to the presence or absence of rash. The chart also indicates any modification of the disease which it was judged had been obtained by the injected globulin. The classification was similar to the one used in Part A, with the obvious exception that a group with no measles could not

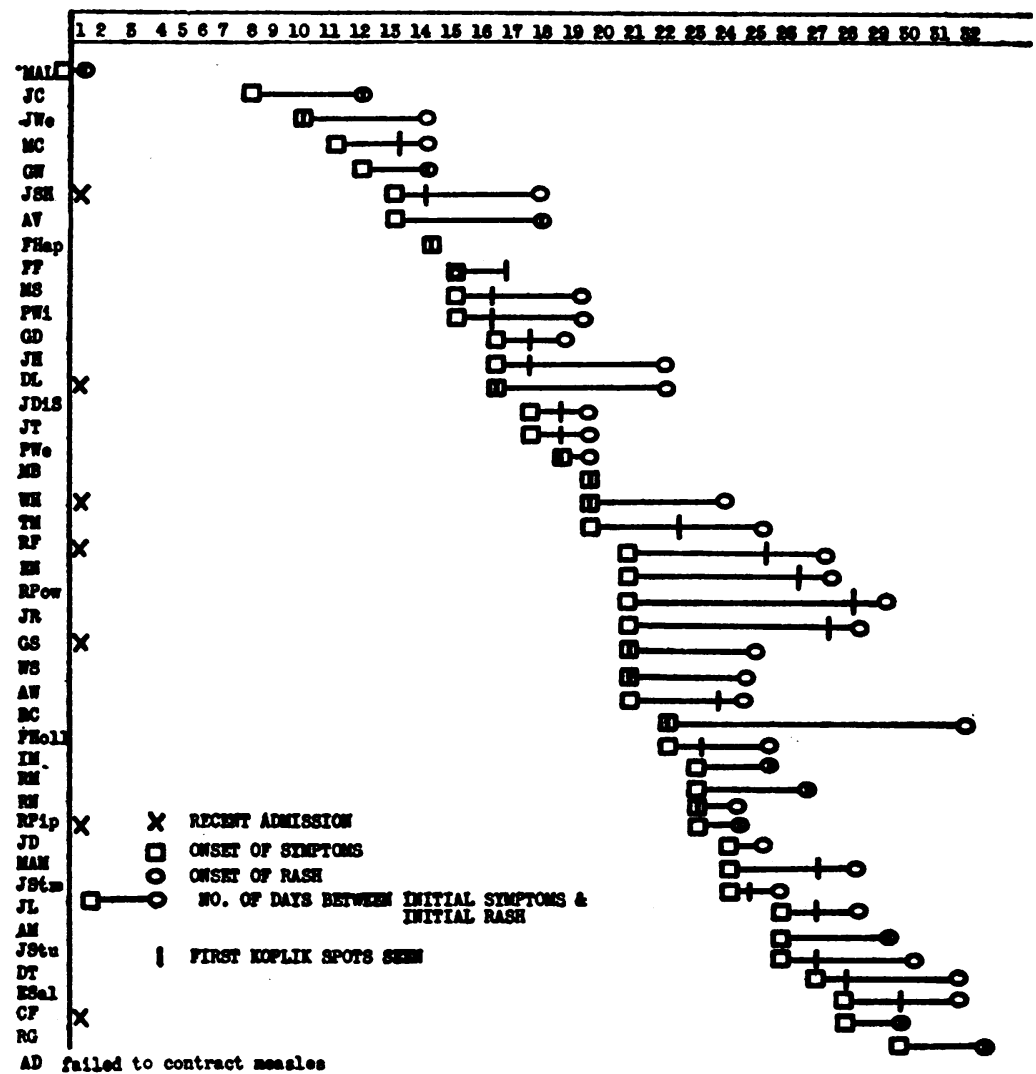

Fig. 3. Progress of Measires Epidemc in a Home for Pre-School Children, Phimadelphia-1943 


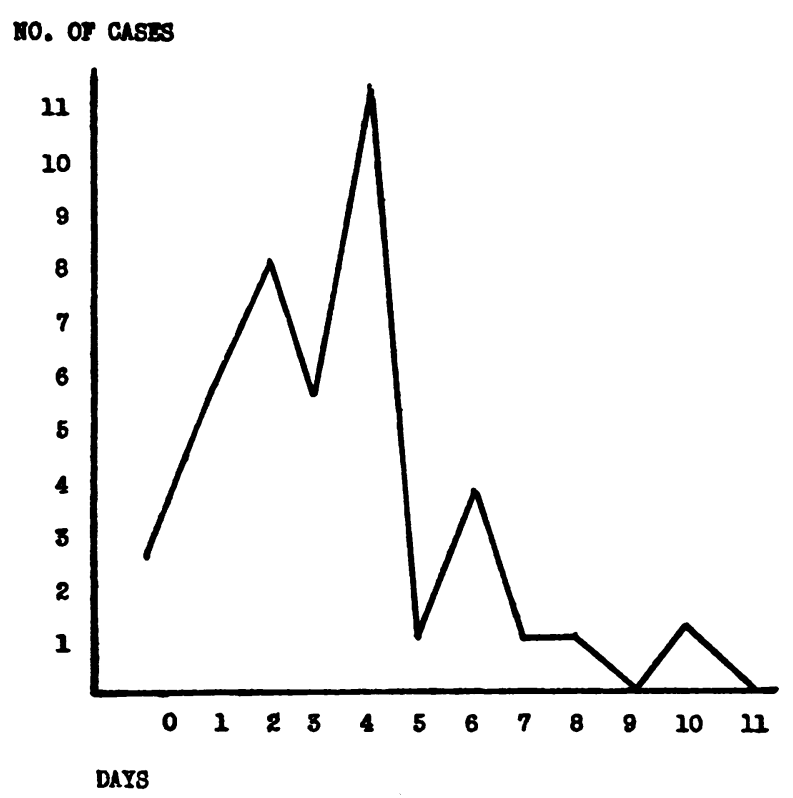

Fig. 4. Number of Days Between Onset of SYMPTONS AND ONSET OF RASH

be included. For a group of this size, judgment as to the value of the globulin in treatment can be more exact than for its value in prophylaxis, because definite alterations in the course and severity of a disease can be noted and even in the early stages of measles some concept of its subsequent severity usually may be obtained. This is well shown by Figure 5 in which the columns appear almost as mirror images. On the other hand, in a study of prophylaxis, alterations in severity can be judged only by the accumulation of a sufficient number of cases for statistical comparison with other large groups. Where feasible, control cases without treatment, occurring at approximately the same time and in the same place, were included, although little importance is attached to obtaining an individual control for each case. As indicated in Part A, greater significance should be attached to over-all severity of the epidemic of which the children are a part than to the severity of the disease in individual controls. The wide variation in susceptibility of different children has been indicated in the curves shown in Figure 2, Part A. Also, it is again worth noting that large families of exposed susceptibilities who have received no human immune bodies will vary greatly in the severity of measles among the individual children. The intimacy of exposure of individual children may be partially responsible for such variations as well as differing susceptibilities, but with such variations in severity of measles, the problem of selecting individual controls remains a difficult one. However, Table IV indicates the comparative severity of the disease in a group of treated children and a group of controls who received no globulin. The controls were either from the same family or had had exposures similar to those of the treated children.

The difference is striking between those 31 individuals treated before the rash appeared, i.e., during the stage of Koplik spots, and 30 treated immediately after the rash appeared. The better results obtained by the earlier use of the globulin are the more striking in consideration of the fact that two children are included in the former group who at no time developed a measles rash, despite a typical onset with many Koplik spots. In both of these children, the fever and other signs and symptoms subsided by crisis. Their occurrence earlier in the course of the study gave greater hope for such therapy in the dosages used than has appeared justified by later findings, however significant these may be. Though only two in number, the result is sufficiently unusual to warrant the conclusion that under the conditions obtaining in these cases, the therapeutic

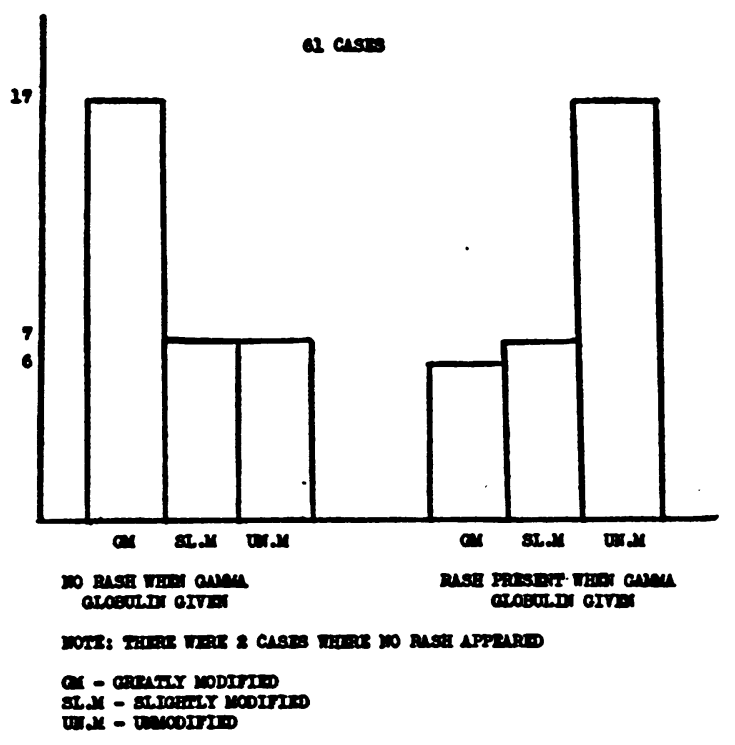

Fig. 5. Therapeutic Use of Gama Globulin in Measles-1943 
agent used had curative value. In addition, 5 children in the same group developed very sparse rashes, while the signs and symptoms of early measles rapidly subsided. In contrast and serving essentially as a control to the first group, the majority of the group of individuals treated after the rash appeared gave no evidence of modification of the disease. Nevertheless, a small number in this group showed considerable modification of the disease.

\section{Discussion}

The small number of individuals treated does not permit final conclusions concerning the value of this type of therapy, although the data offer some hope that gamma globulin Fraction II (also II + III), or other fractions of a higher order of concentration of measles antibodies in similar or larger amounts, may be of considerable therapeutic value in the early stages of measles. Globulin preparations which could be injected intravenously would be possibly of even greater usefulness, particularly if they were obtained from pools of plasma drawn during the early stages of measles convalescence. The practical application of such therapy is problematical unless more potent preparations, administered intravenously, prove to be highly effective even when the rash has appeared, inasmuch as a physician rarely has the opportunity of treating a child during the stage of Koplik spots with no rash. On the other hand, if such therapy, administered before the appearance of rash, on further study proves to be effective, the proper education of parents concerning measles and their awareness of such therapy may result in the earlier treatment of larger numbers of children.

Passive immunization soon after exposure for purposes of attenuation is preferable to such therapy, but the lack of knowledge of exposure is such a common and unavoidable experience that treatment with human immune bodies by this method, if proved effective, would still be useful.

\section{Summary}

The serum gamma globulin, separated and concentrated by chemical fractionation of normal human blood, has been used in studies on the treatment of measles in its early stages. Fraction II + III was used in 8 cases and Fraction II in 53 cases. Dosages ranged from 5 to 35 cc. and ages from 10 months to 34 years.

Of 30 individuals injected after the rash had started, there appeared to be modification of the disease in 13.

Of 31 individuals injected when Koplik spots were present but no rash, there appeared to be modification of the disease in 24 . In 2 of these individuals, no rash developed.

\section{BIBLIOGRAPHY}

1. Cohn, E. J., Oncley, J. L., Strong, L. E., Hughes, W. L., Jr., and Armstrong, S. H., Jr., Chemical, clinical, and immunological studies on the products of human plasma fractionation. I. The characterization of the protein fractions of human plasma. J. Clin. Invest., 1944, 23, 417.

2. Enders, J. F., Chemical, clinical, and immunological studies on the products of human plasma fractionation. X. The concentrations of certain antibodies in globulin fractions derived from human blood plasma. J. Clin. Invest., 1944, 23, 510.

3. Shaffer, M. F., Rake, G., Stokes, J., Jr., and O'Neil, G. C., Studies on measles. II. Experimental disease in man and monkey. J. Immunol., 1941, 41, 241.

4. Ordman, C. W., Jennings, C. G., and Janeway, C. A., Chemical, clinical, and immunological studies on the products of human plasma fractionation. XII. The use of concentrated normal human serum gamma globulin (human immune serum globulin) in the prevention and attenuation of measles. J. Clin. Invest., 1944, 23, 541.

5. Levinson, S. O., Human serum; its value in infectious diseases and as a blood substitute. Tri-state M. J., 1940, 12, 2470. 